\title{
Exchange Rates and Fiscal Adjustments: Evidence from the OECD and Implications for EMU*
}

\author{
Luisa Lambertini \\ University of California at Los Angeles \\ and \\ José Tavares \\ Universidade Nova, Lisbon
}

August, 2003

\begin{abstract}
We study monetary and exchange-rate policies around successful and unsuccessful fiscal adjustments and find that successful adjustments are preceded by large nominal exchange rate depreciations, whereas unsuccessful adjustments are preceded by appreciations. Pre-adjustment depreciation is a significant and quantitatively important predictor of the success of adjustment. Our results are robust to the inclusion of other determinants of the success of adjustment and to the definition of the depreciation period, of the persistence of the adjustment, and of the exchange rate. Monetary policy does not affect the success of fiscal adjustments. This result is confirmed when the sample is divided into countries that follow a fixed exchange rate policy and those that do not: for both cases it is exchange rate depreciations that affect the likelihood of success. Our results suggest that the adoption of a single currency will make successful fiscal adjustments more difficult to attain within EMU.

JEL Classification: E62, E63, F36

Keywords: Exchange Rates, Monetary Policy, Fiscal Adjustments, Economic and Monetary Union.

* We have benefited from the comments of Jordi Gali, Arnold Harberger, Lee Ohanian, Alfredo Marvão Pereira, Aaron Tornell, Carlos Vegh and participants at the UCLA seminar in International and Development Economics and the $6^{\text {th }}$ SPIE Conference 2001. Phillip Lane has kindly provided some of the data used in this paper. José Tavares thanks NOVA FORUM for financial support. The usual disclaimer applies. Addresses of authors: Luisa Lambertini, Department of Economics, UCLA, Los Angeles, CA 90095-1477, USA, tel: (310) 206-1256, e-mail: luisa@econ.ucla.edu; José Tavares, Department of Economics, Universidade Nova, Lisbon, Portugal. E-mail: jtavares@fe.unl.pt*
\end{abstract}




\section{Introduction}

The literature on the effects of fiscal adjustments experienced a revival in the 1990s as the unexpected consequences of major fiscal adjustments in Europe in the eighties renewed our interest in understanding the determinants of their success. Expansions rather than recessions followed sizeable fiscal contractions in Denmark and Ireland, ${ }^{1}$ while the large fiscal expansion in Sweden in the early nineties led to a severe recession. An explanation of such economic outcomes needs to draw on something else than the traditional Keynesian theory of fiscal policy. The literature on the effects of fiscal adjustments has since uncovered several empirical regularities. The size and composition of the fiscal adjustment (how large as share of GDP and how much it relies on spending cuts), as well as the level of public debt at the time, all seem to affect its probability of success. Unexpectedly, the role of monetary and exchange rate indicators, even if frequently alluded to, has not merit similar attention.

Different authors pointed to the potential role of monetary policy and exchange rates before and during successful adjustments. Giavazzi and Pagano (1990) state that "disentangling the effects of wage moderation and the effects of fiscal variables on the supply side and the cost of firms, versus the effect of the exchange rate is a critical next step to understand the dynamics of fiscal adjustments." Alesina and Perotti (1997) mention the role of exchange rates explicitly when discussing avenues for further research: "A very important policy decision concerns the policy mix which should accompany a major fiscal adjustment, particularly the exchange rate policy. Several major successful adjustments have been preceded by devaluations, but the same happened for some of the unsuccessful ones. The question is whether a devaluation helps in determining the success of the adjustment and its macroeconomic consequences." Even if recognized as important, the behavior of monetary and exchange rate policies around fiscal adjustments has not been explicitly investigated. ${ }^{2}$ This is a particularly relevant issue for the eleven European countries that have adopted a common currency by joining the Economic and Monetary Union (EMU) and thereby relinquished the conduct of independent monetary and exchange rate policies.

The goal of this paper is precisely to assess the empirical role of monetary and exchange rate policies on the success of fiscal adjustments. It adds to the literature on fiscal adjustments in two main ways. First, it characterizes the behavior of monetary and exchange rate policy, before, during and after fiscal adjustments, both through the use of case studies and summary statistics. By examining successful and unsuccessful adjustments separately, we highlight the possible contribution of these policies for success. The second contribution is to test the importance of monetary and exchange rate policy explicitly against the success factors that have been previously studied in the literature.

\footnotetext{
${ }^{1}$ Respectively in $1983-86$ and $1987-89$, involving a cut in the deficit of $7.2 \%$ and $5.7 \%$ of GDP.

${ }^{2}$ After completing the current paper, we came across Hjelm (2000), who studies the issue of exchange rate devaluations before fiscal adjustments and obtains results consistent with our findings. While this author studies the response in terms of output growth we focus on the persistence of the adjustment.
} 
Our results can be summarized as follows. Exchange rate depreciations before a fiscal adjustment is initiated significantly increase the probability it will be successful, in the sense that it will bring a permanent improvement in public finances. A one standard deviation increase in rate of depreciation of the real exchange rate in the two years before a fiscal adjustment leads to 11 to 15 percent higher chance of success. When compared with the composition effect, namely the impact of the spending-tax composition of the fiscal adjustment, exchange rate depreciation has a similar quantitative effect since a one standard deviation increase in the spending share of the adjustment leads to a 10 percent higher probability of success. Unlike changes in the exchange rate, monetary policy does not play a significant role in promoting persistence.

These results have important implications for the feasibility of fiscal consolidations in the EMU. Since the ability to devalue the exchange rate is an important element in bringing a fiscal adjustment to a successful end, fiscal adjustments in the EMU are less likely to be successful. This is because of the adoption of a common currency as it denies EMU member states the possibility of undertaking a fiscal adjustment cannot devalue its currency against that of its main trading partners (actually, the other EMU members) or unilaterally against the US Dollar or the Japanese Yen.

The paper is organized as follows. Section 2 briefly reviews the literature on fiscal adjustments. Section 3 examines three episodes of fiscal adjustments, highlighting the role of monetary and exchange rate policies. Section 4 characterizes successful and unsuccessful fiscal adjustments and empirically tests the role of monetary policy and exchange rate devaluation in their success. Section 5 discusses the implications of our results for EMU and concludes.

\section{Fiscal Adjustments: Theory and Evidence}

Fiscal adjustments have been the focus of macroeconomic policy debate in recent years. The members of the EMU, as well as other countries that hope to become members in the future, have pursued large deficit reductions to satisfy the convergence criteria mandated by the Maastricht Treaty. Some Latin American economies have improved their budget balances under the pressure of IMF conditionality and the threat of capital outflows.

A fiscal adjustment, defined as a reduction in the government primary budget deficit, can result from a reduction in government expenditures or an increase in tax revenues. ${ }^{3}$ The theoretical implications of a fiscal adjustment on private consumption and output are different in different models. ${ }^{4}$ Infinite horizon models predict that a permanent reduction in government spending raises private consumption provided public and private consumption have zero or positive substitutability: individuals' permanent income increases because current and future taxes are lower, thereby raising private consumption. ${ }^{5}$

\footnotetext{
${ }^{3}$ This corresponds to a change in the primary deficit. The total deficit may also be cut due to a reduction in the interest paid on the outstanding stock of debt.

${ }^{4}$ For a review of the theoretical literature on fiscal adjustments, see Giavazzi, Japelli and Pagano (2000).

${ }^{5}$ When private and public consumption are complements, the effects of spending cuts are more complex as individuals will tend to reduce private consumption in response to a reduction in public consumption.
} 
Changes in taxes that are not accompanied by changes in current or future public spending have no effects on private consumption or investment: aggregate saving remains unchanged, as changes in public saving lead to compensating changes in private saving. This is the well know Ricardian Equivalence result, as in Barro (1974). Ricardian Equivalence, however, holds only in a world where taxes are non-distortionary, individuals are not credit constrained and there is no uncertainty about future government policies. If current changes in taxes signal future changes in public spending, as suggested by Feldstein (1982), the temporal pattern of taxes has real effects in the economy.

Fiscal adjustments have different effects in overlapping generation models of finitely lived individuals. Cuts in public spending raise private consumption if matched by cuts in taxes, but fail to do so if current taxes remain high. Similarly, changes in taxes lead to changes in private consumption, whether accompanied or not by changes in public spending.

Finally, Keynesian models predict that an increase in government spending has an unambiguous positive effect on output: higher public demand raises production and private spending, notwithstanding some crowding out with respect to private investment due to higher interest rates. Wealth effects can mitigate or reverse this result, as consumption and investment are negatively affected by a decrease in wealth. An increase in taxes with a constant level of public spending, on the other hand, decreases private consumption and interest rates. Investment goes up, but the overall effect on output is negative. Once again, wealth effects mitigate output contraction.

A different class of models proposes that the effects of fiscal policy on output and private consumption are non-linear and depend on the circumstances of adjustment. Factors such as the size and persistence of the fiscal impulse, the level and growth of public debt at the beginning of the adjustment as well as its composition may lead to effects similar to those predicted by infinite horizon models. Blanchard (1990) presents a model where the level of public debt affects the impact of the adjustment on the economy. The effects of distortionary taxation are highly non-linear and households have finite horizons. An increase in net taxes lowers private consumption if public debt is low, but may raise it if public debt is high. This happens because higher current taxes delay the date of adjustment, postpones the deadweight cost of adjustment to future generations and thus increases the lifetime income of existing households. ${ }^{6}$ Other authors have pointed to the possibility of non-linear effects of public spending cuts. Small cuts in public spending have Keynesian effects, while large cuts signal a change in regime and thus lead to increases in private consumption. This has been suggested in Feldstein (1982) and Drazen (1990); Bertola and Drazen (1993) propose a similar nonlinearity on the basis of an expected probability of stabilization that arises when

\footnotetext{
${ }^{6}$ Sutherland (1997) proposes a similar mechanism. If an adjustment is expected when public debt reaches a certain threshold, a rise in taxes when the economy is closer to the threshold delays adjustment and thus may increase the lifetime wealth of finite-horizon households. Perotti (1999) proposes a model where some households are liquidity constrained. A decrease in the deficit lowers consumption of liquidity-constrained households (through a rise in taxes) and increases that of unconstrained households (through spending cuts). Which effect dominates depends on the ratio of public debt to GDP: when it is high tax the positive effect on consumption dominates.
} 
spending reaches a pre-determined threshold. ${ }^{7}$ Feldstein (1982) suggests that the magnitude of the fiscal adjustment in itself may signal its persistence, leading to non-linear effects of the size of the deficit cut on the economy.

A number of researchers have taken the question of whether fiscal adjustments are expansionary to the data. Giavazzi and Pagano $(1990,1996)$ started this empirical literature with the analysis of the Danish stabilization of 1983-86 and the Irish stabilization of 1987-89. They conclude that, in both cases, the fiscal adjustments were so large that private consumption increased in response to an upward revision of permanent income's estimates. Giavazzi, Jappelli and Pagano (2000) search for non-Keynesian responses of national saving to fiscal policy and find them to be associated to large and persistent fiscal impulses, especially during fiscal contractions, confirming the findings in Giavazzi and Pagano (1996).

Another factor that has been associated with success of fiscal adjustments is the fiscal stance at the time of adjustment. On one hand, Perotti (1999) has provided evidence that the higher the level of debt (or the more rapid the growth of public deficits), the more likely for the fiscal adjustment to have expansionary effects. On the other hand, Giavazzi, Jappelli and Pagano (2000) find that a high or rapidly growing debt/GDP ratio does not predict non-Keynesian responses to fiscal adjustments.

Alesina and Perotti (1996), Alesina, Perotti and Tavares (1998) and Alesina and Ardagna (1998) classify fiscal adjustments on the basis of their ex-post performance: adjustments are successful if, three years down the road, the debt/GDP ratio has fallen at least 5 percentage points. They find that composition matters: cutting spending rather than raising taxes leads to more persistent improvements of public finances and is usually accompanied by an increase in GDP. Conversely, Giavazzi, Jappelli and Pagano (2000) find that composition matter, but in the opposite way: fiscal contractions are expansionary if carried out by tax increases rather than spending cuts.

\section{Case Studies of Large Fiscal Adjustments}

Earlier analyses of the 1980's fiscal retrenchments in Ireland, Denmark and Sweden have focused on their size, persistence and composition. These studies have asked which of the factors is most important in making an adjustment successful or expansionary. While suggesting that monetary and exchange rate policies may have played a role, there is no systematic assessment of their importance. In this section, we review these major episodes of fiscal adjustment with a view to highlight the role of exchange rate and monetary policy.

\subsection{Ireland}

From 1974 to 1983, the Irish public finances had deteriorated steadily, bringing public debt from $55 \%$ to about $95 \%$ of GDP. At the same time, the

\footnotetext{
${ }^{7}$ The mechanics of the argument work in a way similar to the Blanchard (1990) and Sutherland (1997) arguments with public spending taking the role of taxes and public debt, respectively.
} 
current account also deteriorated, reaching a staggering $13.7 \%$ of GDP in 1981 . According to our definition of adjustment, ${ }^{8}$ Ireland had three episodes of fiscal adjustment since 1980: 1983-84, 1987-89 and 1996. The main features of these fiscal adjustments are summarized in Table 1 below.

Table 1: Fiscal adjustments in Ireland

\begin{tabular}{l|ccc}
\hline & $\mathbf{1 9 8 3 - 8 4}$ & $\mathbf{1 9 8 7 - 8 9}$ & $\mathbf{1 9 9 6}$ \\
\hline Successful & Yes & Yes & No \\
Average real GDP growth differential & 1.4 & 5 & 0.6 \\
Total primary surplus/GDP change & 4.3 & 8.3 & 1.7 \\
Average primary surplus/GDP change & 2.2 & 2.8 & 1.7 \\
Initial net debt/GDP & 83.3 & 116.3 & 84.3 \\
Composition & 53.7 & 151.5 & 64.7 \\
DM/Punt depreciation before adjustment (\%) & $\mathbf{1 6}$ & $\mathbf{1 5}$ & $\mathbf{3}$ \\
M1 growth differential & $\mathbf{- 8 . 2} *$ & $\mathbf{6 . 3}$ & $\mathbf{- 2 7}$ \\
*: M3 & & & \\
\hline
\end{tabular}

Of the three adjustments, those in 1983-84 and 1987-89 were successful, while the 1996 adjustment was unsuccessful. The second row of Table 1 reports the impact of the adjustment on real GDP growth (measured as the difference between average growth during and in the two years before the adjustment). All three adjustments were expansionary, especially the 1987-89 and the 1983-84. The third and fourth rows report the total and average improvement in the primary balance to GDP, respectively while row five reports the debt/GDP ratio at the beginning of the adjustment. The fiscal impulse in 1987-89 was the strongest and it coincided with the peak in the ratio of public debt to GDP. Row six reports the (average) composition of the fiscal adjustment, indicating what fraction of the improvement in primary surplus was due to a reduction in government spending versus an increase in tax revenues. ${ }^{9}$ Most of the fiscal improvement in 1983-84 came through cuts in discretionary taxation; the 1987-89 adjustment, on the other hand, relied on massive reductions in government outlays, which fell from $50 \%$ to $38 \%$ of GDP in three years. The 1996 fiscal improvement came from a combination of lower public spending and higher income taxes on households.

Row seven of Table 1 reports the developments in Irish monetary policy ${ }^{10}$ during the fiscal adjustments. The fiscal tightening of 1983-84 and 1996 were accompanied by sharp contractions in money supply, while the 1987-89 adjustment was accompanied by a monetary expansion. Row eight shows the depreciation of the German DM/Irish punt exchange rate in the two years before the adjustment: the two successful adjustments, 1983-84 and 1987-89, were preceded by large depreciations whereas the unsuccessful 1996 adjustment was not.

\footnotetext{
${ }^{8} \mathrm{~A}$ fiscal adjustment is an improvement of the primary balance to GDP ratio of at least $1.5 \%$ in a single year. An adjustment is successful if the changes in the deficit in the two years immediately after the adjustment are zero or negative. In later sections we also consider a three-year definition of success.

${ }^{9}$ A figure above $100 \%$ indicates that the cut in government spending was accompanied by a reduction in tax revenues.

${ }^{10}$ This is the difference in the average growth rate of M1 during and the three years before the stabilization.
} 
The DM/Punt exchange rate ${ }^{11}$ and the real effective exchange rate ${ }^{12}$ are shown in Figures 1 and 2, respectively. At the onset of the first fiscal adjustment, on March 21, 1983, the Irish Punt was devalued by 3.5 percent with respect to the $\mathrm{DM}$; this realignment was accompanied by the announcement of a stronger commitment by the Irish Central Bank to maintain the new. As a result, inflation slowed down and the real exchange rate depreciated sharply, as evident in Figure 2. The boost to competitiveness improved the current account/GDP ratio by 4 percentage points and the reduction in interest rates stimulated the demand for domestic products and investment.

[Figures 1 and 2 about here]

The Irish Punt was devalued again by 8 percent against the DM in August 1986, well before the 1987-89 stabilization had started. The devaluation offset the loss of competitiveness suffered in 1985-86 due to the depreciation of the sterling. ${ }^{13}$ In addition, a reduction in the rate of wage increases and gains in relative productivity led to a sustained improvement in competitiveness throughout the stabilization, as shown in Figure 2. The credibility of the exchange rate commitment further reduced interest rates and gave a remarkable impulse to domestic investment: business investment rose by 17 percent and household investment rose by 11 percent during the adjustment.

The Irish pound was devalued by 7 percent against the DM during the 1993 attacks on the EMS currencies that led to the widening of the currency bands. In the final stage of convergence toward the EMU, however, Ireland could not devalue its currency because of the requirements of the Maastrich Treaty; as a result, Ireland's real exchange rate appreciated by more than 10\% between 1993 and 1997. The fiscal tightening of 1996, although limited in size, was unsuccessful and failed to raise output growth substantially.

\subsection{Denmark}

After a rapid deterioration of public finances that brought public debt from 12 to 65.5 percent of GDP and pushed interest rates above 20 percent, a minority Conservative coalition government adopted a sweeping stabilization that abolished the semi-automatic regulation of public sector wages, put a freeze on public investment and unemployment benefits, and increased social security contributions, direct and indirect taxation. The main features of the program are summarized in Table 2 . The adjustment was successful and expansionary: business investment increased by 30 percent and household investment by 20 percent at the beginning of the program, and they continued to grow until 1986. The primary budget/GDP improved by almost 14 percent; on average, half of the primary surplus improvement came from lower government expenditures and the other half came from higher tax revenues.

\footnotetext{
${ }^{11}$ Measured as the number of DMs for one Irish Punt.

${ }^{12}$ The real effective exchange rate is normalized to 100 in June 1982; a fall of the rate is a real depreciation of the Irish Punt.

${ }^{13}$ The United Kingdom is Ireland's principal trading partner.
} 


\section{Table 2: Fiscal adjustment in Denmark}

\begin{tabular}{l|c}
\hline & $\mathbf{1 9 8 3 - 8 6}$ \\
\hline Successful & Yes \\
Average real GDP growth differential & 2.6 \\
Total primary surplus/GDP change & 13.8 \\
Average primary surplus/GDP change & 3.5 \\
Initial net debt/GDP & 65.5 \\
Composition & 51.0 \\
M1 growth differential & $\mathbf{7 . 7}$ \\
DM/Krona depreciation before adjustment $(\%)$ & $\mathbf{1 5}$ \\
\hline
\end{tabular}

Interestingly, the Danish adjustment was accompanied by an expansion in money supply and a depreciation in the DM/Danish Krona exchange rate of 15 percent in the two years that preceded the adjustment. Three devaluations between October 1981 and June 1982 resulted in large gains in competitiveness (see Figures 3 and 4), so that Danish competitiveness was at an all time peak when the fiscal program got under way in October 1982. The combination of fiscal adjustment and credible exchange rate policy more than halved inflation and interest rates between 1982 and 1986.

[Figures 3 and 4 about here]

\subsection{Sweden}

Sweden embarked in two large fiscal adjustments in 1983-87 and 1994-96, whose features are summarized in Table 3. Sweden developed twin external and public finance problems in the early 1980s, leading to the doubling of public debt as a share of GDP between 1976 and 1982. The Social Democratic government that took office in September 1982 embarked on a wide-ranging program aimed at reducing central government expenditures, ${ }^{14}$ as reflected in the composition variable. The adjustment was successful and expansionary.

Table 3: Fiscal adjustments in Sweden

\begin{tabular}{l|cc}
\hline & $\mathbf{1 9 8 3 - 8 7}$ & $\mathbf{1 9 9 4 - 9 6}$ \\
\hline Successful & Yes & Yes \\
Average real GDP growth differential & 2.1 & 4.5 \\
Total primary surplus/GDP change & 5.9 & 10.2 \\
Average primary surplus/GDP change & 2.1 & 3.8 \\
Initial net debt/GDP & 66.3 & 83.9 \\
Composition & 252.4 & 86.5 \\
M1 growth differential & $\mathbf{- 3 . 3}$ & $\mathbf{0 . 3}$ \\
DM/Krona depreciation before adjustment $(\boldsymbol{\%})$ & $\mathbf{3 8}$ & $\mathbf{2 5}$ \\
\hline
\end{tabular}

A key element of the 1983-87 adjustment was a 10 percent devaluation of the Swedish Krona, which was pegged to a trade-weighted currency basket, in

\footnotetext{
${ }^{14}$ In particular, health insurance benefits, transfers to local authorities, rent subsidies and wages in the educational system were reduced.
} 
September 1981 followed by 16 percent devaluation in October 1982. This is shown in Figure 5. As a result, competitiveness improved by 30 percent during that period, as is clear in Figure 6. Monetary policy was tightened during the adjustment; inflation more than halved by the end of the fiscal adjustment and interest rates fell and investment rose sharply.

[Figures 5 and 6 about here]

The 1994-96 adjustment was triggered by the sharp deterioration of public finances caused by the 1991-93 recession, the longest and deepest in Swedish postwar history. The adjustment was large - it lowered public debt by more than 10 percent of GDP - and successful; its composition was a mix of spending cuts, higher taxes and social-security contributions and privatization. A key feature of this stabilization program is that it came at a peak of Swedish competitiveness. In May 1991, the Swedish Krona was pegged to the ECU as part of the government's intention to seek full membership of the European Community; in November 1992, however, a speculative attack forced the Swedish Central Bank to float the Krona, which depreciated by 17 percent in just one month. As a result, the real exchange rate depreciated sharply, raising external demand and improving the current.

The six adjustment episodes reviewed in this section present us with mixed evidence on the importance that composition, size, and the fiscal stance at the time of the adjustment have on the final success of the consolidation. All six adjustments were expansionary, but one (the Irish 1996 adjustment) was unsuccessful. Three successful adjustments were a mix of spending cuts and taxes. Public debt at the time of the adjustment as well as the average size of the fiscal adjustment was similar for both successful and unsuccessful episodes. Three successful adjustments were accompanied by monetary expansions while two of them by monetary contractions. By contrast, the evidence on the importance of exchange rate devaluation appears more robust. Sizeable devaluations preceded all episodes of successful fiscal adjustment. The unsuccessful adjustment, i.e. Ireland in 1996, was the only episode not preceded by sizable exchange rate depreciation.

\section{Empirics}

In this section we assess the role of exchange rates and money supply in the sustainability of fiscal adjustments. Specifically, we analyze the role of monetary and exchange rate policies in light of the determinants of successful adjustments studied in the literature. Our data on fiscal, monetary and output data refers to 20 OECD countries between the years 1970 to $1999 .{ }^{15}$ Fiscal and output data are from the OECD Economic Outlook. A shorter version of this data set has been widely used in the empirical literature on fiscal adjustments. The data on money supply are from the International Monetary Fund's International Financial Statistics. Appendix I provides a complete description of the data series, including sources, units and transformations.

\footnotetext{
15 The countries are Australia, Austria, Belgium, Canada, Denmark, Finland, France, Germany, Greece, Ireland, Italy, Japan, Netherlands, New Zealand, Norway, Portugal, Spain, Sweden, United Kingdom and the United States.
} 
We define a period of fiscal adjustment as a year when the primary deficit is cut by at least 1.5 percent of GDP. This is a rather stringent definition of fiscal adjustment. As an illustration, the sustained output expansion in the United States from the mid-1990's to 2000 has led to a marked decrease in the budget deficit but does not register a single "adjustment year" according to our criterion. Adjustment years are then subdivided into successful and unsuccessful. A fiscal adjustment is successful when the primary deficit does not increase in the two or in the three years immediately after the year of the deficit cut. All other cases of fiscal adjustment are classified as unsuccessful. In our sample there are 99 fiscal adjustments, of which 50 are successful according to our two-year definition and 47 are according to our three-year definition.

Table 4 presents summary statistics for the monetary and exchange rate variables around the time of adjustments. We present random-effects panel data estimates of regressions of each monetary variable on dummy indicators for periods just before, during and just after fiscal adjustments. Our results clearly show that before and during successful adjustments there are depreciations (or devaluations) ${ }^{16}$ of the exchange rate. This is independent of the definition of the exchange rate employed. In contrast, there is little action in monetary policy before successful adjustments. If anything, an increase in money supply before an adjustment is associated with a smaller likelihood of success.

What we do next is empirically test, for the first time, whether the depreciation in the exchange rate affects the sustainability of the fiscal adjustment and whether that impact is robust to other determinants of successful adjustments. We are thus able to quantify the relative importance of each factor in determining success. We use a panel random effects specification where the dependent variable is a dummy variable that takes the value 1 in case of success. ${ }^{17}$

\footnotetext{
${ }^{16}$ We analyze exchange rate regimes later on.

${ }^{17}$ Success is measured by a dummy with value 1 in years when the primary deficit to GDP ratio decreases by $1.5 \%$ and followed by years when the primary deficit does not increase. We use 2 and 3 years after the fiscal adjustment as alternative criteria for success.
} 
Table 4

Exchange Rate, Money Supply and Fiscal Adjustments

\begin{tabular}{|c|c|c|c|c|c|}
\hline & & \multicolumn{3}{|c|}{ Exchange Rate } & \multirow{2}{*}{$\begin{array}{c}\begin{array}{c}\text { Money } \\
\text { Supply }\end{array} \\
\text { M1 }\end{array}$} \\
\hline & Timing & Effective & USD & $\begin{array}{l}\text { Deutsche } \\
\text { Mark }\end{array}$ & \\
\hline \multirow[t]{3}{*}{$\begin{array}{c}\text { Successful } \\
\text { Adjustments }\end{array}$} & Before & $\begin{array}{l}-2.64 * * \\
(-3.22)\end{array}$ & $\begin{array}{l}-2.21 \\
(-1.53)\end{array}$ & $\begin{array}{c}-0,96 \\
(-0,95)\end{array}$ & $\begin{array}{c}-1,70 \\
(-0,95)\end{array}$ \\
\hline & During & $\begin{array}{c}-1.99 * * \\
(-2.41)\end{array}$ & $\begin{array}{l}-2.83^{*} \\
(-1.92)\end{array}$ & $\begin{array}{c}-2,51 * * \\
(-2,41)\end{array}$ & $\begin{array}{c}-0,58 \\
(-0,31)\end{array}$ \\
\hline & After & $\begin{array}{l}2.06^{* *} \\
(2.59)\end{array}$ & $\begin{array}{l}1.39 \\
(0.96)\end{array}$ & $\begin{array}{c}-0,43 \\
(-0,42)\end{array}$ & $\begin{array}{c}-0,01 \\
(-0,01)\end{array}$ \\
\hline \multirow[t]{3}{*}{$\begin{array}{l}\text { Unsuccessful } \\
\text { Adjustments }\end{array}$} & Before & $\begin{array}{c}-0.54 \\
(-0.77)\end{array}$ & $\begin{array}{l}2.99 * * \\
(2.39)\end{array}$ & $\begin{array}{c}0,24 \\
(0,28)\end{array}$ & $\begin{array}{l}2,69 * \\
(1,74)\end{array}$ \\
\hline & During & $\begin{array}{l}-0.25 \\
(-0.32)\end{array}$ & $\begin{array}{l}-0.39 \\
(-0.28)\end{array}$ & $\begin{array}{l}2,96 * * \\
(2,97)\end{array}$ & $\begin{array}{l}-1,22 \\
(-0,72)\end{array}$ \\
\hline & After & $\begin{array}{l}-1.16^{*} \\
(-1.68)\end{array}$ & $\begin{array}{c}-0.73 \\
(-0.58)\end{array}$ & $\begin{array}{c}-0,18 \\
(-0,20)\end{array}$ & $\begin{array}{c}0,73 \\
(0,48)\end{array}$ \\
\hline R2 Overall & & 0.04 & 0.02 & 0.02 & 0,01 \\
\hline $\begin{array}{c}\text { Number of } \\
\text { Observations }\end{array}$ & & 752 & 684 & 760 & 680 \\
\hline
\end{tabular}

Note: The Table presents random-effects panel data estimates of the response of each of the definitions of exchange rates and of money supply to periods just before, during and just after successful and unsuccessful adjustments. The t-statistic is presented in parenthesis below the coefficient. The Change in Exchange Rate is defined such that a positive value denotes an appreciation. $*$ and $* *$ indicate a significant coefficient respectively at the $10 \%$ and the $5 \%$ confidence levels.

Next we test empirically, and for the first time, whether the depreciation of the exchange rate affects the sustainability of the fiscal adjustment and whether this impact is robust to other determinants of successful adjustments. We are thus able to quantify the relative importance of each factor in determining success. We use a panel random effects specification where the dependent variable is a dummy variable that takes the value 1 in case of success. ${ }^{18}$

Different characteristics of fiscal adjustment episodes have been associated with its persistence in time. In a seminal paper examining the large fiscal adjustments of the 1980's in Denmark and Ireland, Giavazzi and Pagano (1990) inferred that the size of the adjustment had a role in reversing individual expectations regarding future fiscal policy: large adjustments tended to be noncontractionary as regards output. Giavazzi and Pagano (1996) later confirmed that the response of the private sector to cuts in the deficit varied with the size of the fiscal impulse. ${ }^{19}$

One of the most robust results to emerge in the literature relates the composition of the fiscal adjustment with its persistence. Alesina and Perotti (1995) first pointed that if the cut in the deficit relies mostly on public spending cuts, it is more likely to be successful and lead to output expansions. Specifically, successful adjustments are associated with cuts in wage government spending and transfers, whereas non-successful adjustments rely mostly on public investment

\footnotetext{
${ }^{18}$ Success is measured by a dummy with value 1 in years when the primary deficit to GDP ratio decreases by $1.5 \%$ and followed by years when the primary deficit does not increase. We use 2 and 3 years after the fiscal adjustment as alternative criteria for success.

${ }^{19}$ Giavazzi, Japelli and Pagano (2000) find a non-linear effect related to the size and persistence of the impulse. Non-linearities are particularly apparent for the case of increases in net taxes and during fiscal contractions.
} 
cuts. $^{20}$ As demonstrated by Alesina and Ardagna (1998) and Alesina and Perotti (1995), the response of the private sector to the adjustment depends on whether spending cuts or tax increases prevail. ${ }^{21}$

Several empirical studies have shown that fiscal adjustments may have expansionary effects. Perotti (1999) examines adjustments in "good" and "bad" times, the latter being periods when the level of public debt is either high or rising fast. This author finds that adjustments are more likely to be expansionary in bad times. However, Giavazzi, Japelli and Pagano (2000) find no evidence that either the level or the rates of increase in public debt are good predictors of non-linear responses. $^{22}$

We use the empirical literature above to guide our specification and test for the role of exchange rates and monetary policy in determining success. Our benchmark specification is thus:

Success $(\mathrm{t})=\alpha+\beta_{1} *$ Level of Public Debt (t-1) $+\beta_{2} *$ Real GDP growth (t1) $+\beta_{3} *$ Change in Public Deficit $(t)+\beta_{4} *$ Change in Government Consumption (t) + $\beta_{5} *$ Change in M1 Money Supply $(\mathrm{t}-1, \mathrm{t}-2)+\beta_{6} *$ Change in the Exchange Rate $(\mathrm{t}-1$, $\mathrm{t}-2)+\varepsilon(\mathrm{t})$

where $(\mathrm{t})$ refers to the time period, $(\mathrm{t}-1)$ to the lagged value and $(\mathrm{t}-1, \mathrm{t}-2)$ to the average lagged value in periods $\mathrm{t}-1$ and $\mathrm{t}-2$. Our variables of interest are the changes in the exchange rate and in M1 in the two years preceding the adjustment. The control variables are: Level of Public Debt (t-1), i.e. Government Net Financial Liabilities as percent of GDP in the year preceding the adjustment; Real GDP growth (t-1), i.e. the rate of growth in real GDP the year before the adjustment; ${ }^{23}$ Change in Public Deficit (t), i.e. the contemporaneous change in the public deficit, corrected for the cycle; Change in Government Consumption (t), i.e. the contemporaneous change in government consumption. We also interact the changes in M1 and in the exchange rate with an indicator for the type of exchange rate regime in place just before the adjustment. ${ }^{24}$

Tables 5 and 6 present the results. Table 5 uses the whole sample to identify the strongest predictors of success in fiscal adjustment, for different definitions of success and different measures of exchange rate depreciation. Columns (1) through (4) add, in turn, each of the determinants of a successful adjustment identified in the literature to the lagged changes in money supply and in the exchange rate. The lagged change in the exchange rate always delivers an estimate of the coefficient that is negative sign and statistically different from zero. This suggests that a depreciation in the currency before the adjustment - associated with a decrease in exchange rate in our definition - increases the probability that

\footnotetext{
${ }^{20}$ Alesina, Perotti and Tavares (1998) have confirmed these results.

${ }^{21}$ All the above-mentioned papers explain the diverging effects with differences in credibility. Higher credibility is associated to stronger positive private sector response.

${ }^{22}$ Except in the case of developing countries and the rate of public debt accumulation.

${ }^{23}$ The inclusion of GDP growth also corrects for the phase of the business cycle at the time of the fiscal adjustment. Nevertheless, our results do not change when this variable is omitted.

${ }^{24}$ A country is NOT under a fixed exchange rate regime if its exchange rate was classified by the International Monetary Fund as a "freely floating regime" (between 1970 and 1974), the exchange rate is not maintained in "relatively narrow bands" (between 1974 and 1978) or it is "independently floating" (after 1978).
} 
the fiscal adjustment persists in time. In contrast, money supply does not seem to affect the likelihood of success. Concerning the controls, we find that lagged growth in GDP, the size of the fiscal adjustment and its composition all significantly impact the persistence of the adjustment, while the level of public debt before the adjustment does not. When all controls are entered simultaneously the same pattern of significant coefficients emerges: large cuts in the fiscal deficit that rely on decreases in public consumption and occur during a contraction in GDP and after a depreciation of the exchange rate lead to successful, i.e. sustainable, fiscal adjustments. This is true independently of the definition of success (based on fiscal variables two or three years after adjustment) and of the definition of exchange rate employed - effective, relative to the US Dollar and relative to the Deutsche Mark. The latter results are presented in Table 5, columns (5) through $(10) .^{25}$

An important issue is whether the countries analyzed were under a fixed or a flexible exchange rate regime. The rationale is that in a fixed exchange rate regime - as in the standard Mundell-Fleming model - money supply is determined by the defense of the parity so that the policy variable that can actually be manipulated is a change in the parity. In a flexible exchange rate regime, quite to the contrary, it is money supply that determines the value of the exchange rate. Table 6 interacts the changes in the exchange rate and in money supply with an indicator for exchange rate regime. A country is classified as a "Fixer" or "NonFixer" using the IMF International Financial Statistics classification of exchange rate regimes, as detailed in Appendix $\mathrm{I}^{26}$ The interaction terms can help us identify if the mechanisms above are present, namely if it is money supply or exchange rate changes that matter according to the policy regime.

The results in Table 6 suggest that, irrespective of the exchange rate regime, a devaluation/depreciation furthers the likelihood of success in a fiscal adjustment. The negative coefficients on the lagged change in the exchange rate tend to be associated with higher levels of significance in the case of flexible exchange rates. This is consistent with Lane and Perotti (1998), who present empirical evidence that a fiscal adjustment is associated with an expansion of exports and the effect is "reinforced if the fiscal reform is accompanied by a flexible exchange rate or a devaluation". The size of the deficit cut and the reliance on cuts in government consumption remain important determinants of success whereas money supply remains irrelevant.

These econometric tests deliver a clear message: as suggested in the empirical and theoretical literature surveyed above, the size and the composition of the fiscal adjustment are key to its persistence, with composition having a quantitatively stronger effect; a depreciation of the domestic currency also facilitates the success of the fiscal adjustment irrespectively of the exchange rate regime in place; money supply does not influence the persistence of the fiscal adjustment; bad times, as indicated by lower growth but not by the level of public debt, improve the likelihood of success.

\footnotetext{
${ }^{25}$ The same results hold if we use a one-year lag change in the exchange rate and in money supply.

${ }^{26}$ Essentially, countries classified by the IMF as pursuing and independent float policy are classified as "NonFixers" and all others - independently of the type of peg or band restricting exchange rate movements - are classified as "Fixers".
} 
Table 5

Exchange Rates and Fiscal Adjustments - All Countries

\begin{tabular}{|c|c|c|c|c|c|c|c|c|c|c|}
\hline & \multicolumn{7}{|c|}{ Success 3 Years Hence } & \multicolumn{3}{|c|}{ Success 2 Years Hence } \\
\hline & $\begin{array}{c}\text { (1) } \\
\text { Effective }\end{array}$ & $\begin{array}{c}\text { (2) } \\
\text { Effective }\end{array}$ & $\begin{array}{c}\text { (3) } \\
\text { Effective }\end{array}$ & $\begin{array}{c}(4) \\
\text { Effective }\end{array}$ & $\begin{array}{c}\text { (5) } \\
\text { Effective }\end{array}$ & $\begin{array}{c}(6) \\
\text { US Dollar }\end{array}$ & $\begin{array}{l}\text { (7) } \\
\text { DM }\end{array}$ & $\begin{array}{c}(8) \\
\text { Effective }\end{array}$ & $\begin{array}{c}(9) \\
\text { US Dollar }\end{array}$ & $\begin{array}{l}\text { (10) } \\
\text { DM }\end{array}$ \\
\hline Lagged Debt & $\begin{array}{c}0,05437 \\
(1.54)\end{array}$ & & & & $\begin{array}{c}-0,00904 \\
(-0.26)\end{array}$ & $\begin{array}{c}-0,00362 \\
(-0.10)\end{array}$ & $\begin{array}{c}-0,0028 \\
(-0.08)\end{array}$ & $\begin{array}{c}-0,03395 \\
(-0.95)\end{array}$ & $\begin{array}{c}-0,02748 \\
(-0.76)\end{array}$ & $\begin{array}{c}-0,02815 \\
(-0.79)\end{array}$ \\
\hline Lagged GDP growth & & $\begin{array}{c}-1,05922 * * \\
(-2.51)\end{array}$ & & & $\begin{array}{c}-1,25583 * * \\
(-2.26)\end{array}$ & $\begin{array}{c}-0,93032 \\
(-1.56)\end{array}$ & $\begin{array}{c}-1,39558^{* *} \\
(-2.49)\end{array}$ & $\begin{array}{c}-1,02993 * \\
(-1.80)\end{array}$ & $\begin{array}{c}-0,68481 \\
(-1.13)\end{array}$ & $\begin{array}{c}-1,16802 \\
(-2.04)\end{array}$ \\
\hline Change in Deficit & & & $\begin{array}{c}-5,11425^{* *} \\
(-7.27)\end{array}$ & & $\begin{array}{c}-4,52188 * * \\
(-5.84)\end{array}$ & $\begin{array}{c}-4,38503 * * \\
(-5.46)\end{array}$ & $\begin{array}{c}-4,60173^{* *} \\
(-5.91)\end{array}$ & $\begin{array}{c}-5,62973 * * \\
(-7.08)\end{array}$ & $\begin{array}{c}-5,47535 \\
(-6.72)\end{array}$ & $\begin{array}{c}-5,69812 \\
(-7.14)\end{array}$ \\
\hline Change in Gov Consumption & & & & $\begin{array}{c}-11,35^{* *} \\
(-6.46)\end{array}$ & $\begin{array}{c}-9,59 * * \\
(-4.30)\end{array}$ & $\begin{array}{c}-10,26^{* *} \\
(-4.40)\end{array}$ & $\begin{array}{c}-9,91 * * \\
(-4.42)\end{array}$ & $\begin{array}{c}-11,57 * * \\
(-5.05)\end{array}$ & $\begin{array}{l}-12,13 \\
(-5.13)\end{array}$ & $\begin{array}{l}-11,87 \\
(-5.16)\end{array}$ \\
\hline Lagged Change in Exchange Rate & $\begin{array}{c}-1,38235^{* *} \\
(-5.44)\end{array}$ & $\begin{array}{c}-1,30763 * * \\
\quad(-5.88)\end{array}$ & $\begin{array}{c}-1,07762 * * \\
\quad(-4.64)\end{array}$ & $\begin{array}{c}-1,05641 * * \\
(-4.79)\end{array}$ & $\begin{array}{c}-1,09567 * * * \\
(-4.41)\end{array}$ & $\begin{array}{c}-0,51898 * * \\
(-3.48)\end{array}$ & $\begin{array}{c}-0,73199 * * \\
(-3.63)\end{array}$ & $\begin{array}{c}-1,09884 * * \\
(-4.31)\end{array}$ & $\begin{array}{c}-0,5326 \\
(-3.52)\end{array}$ & $\begin{array}{c}-0,78481 \\
(-3.79)\end{array}$ \\
\hline Lagged Change in M1 & $\begin{array}{c}-0,21403 \\
(-1.41)\end{array}$ & $\begin{array}{c}-0,17314 \\
(-1.33)\end{array}$ & $\begin{array}{c}-0,14267 \\
(-1.16)\end{array}$ & $\begin{array}{c}-0,09655 \\
(-0.82)\end{array}$ & $\begin{array}{c}-0,14758 \\
(-1.01)\end{array}$ & $\begin{array}{c}-0,04547 \\
(-0.31)\end{array}$ & $\begin{array}{c}-0,12151 \\
(-0.82)\end{array}$ & $\begin{array}{c}-0,16523 \\
(-1.10)\end{array}$ & $\begin{array}{c}-0,05451 \\
(-0.36)\end{array}$ & $\begin{array}{c}-0,14805 \\
(-0.98)\end{array}$ \\
\hline R2 Within & 0,06 & 0,06 & 0,14 & 0,12 & 0,21 & 0,20 & 0,20 & 0,25 & 0,25 & 0,25 \\
\hline R2 Between & 0,32 & 0,24 & 0,44 & 0,35 & 0,38 & 0,45 & 0,38 & 0,28 & 0,40 & 0,29 \\
\hline Nr. Observations & 460,00 & 580,00 & 466,00 & 530,00 & 421,00 & 392,00 & 421,00 & 421,00 & 392,00 & 421,00 \\
\hline
\end{tabular}

Note: The coefficient is interpreted as the percentage change in the dependent variable - success of the fiscal adjustment- for a 1 percent change in the independent variable. The controls used are the rate of growth of real GDP, Gross National Public Debt as share of GDP a year before the fiscal adjustment; the change in the public deficit during the adjustment and the contemporaneous change in government consumption. The Lagged Change in Exchange Rate and the Lagged Change in M1 are, respectively, the change in the exchange rate (a positive value denotes an appreciation) and in M1 in the two-years before the adjustment. The t-statistic is presented in parenthesis below the coefficient. * and $* *$ indicate a significant coefficient respectively at the $10 \%$ and the $5 \%$ confidence levels. 
Table 6

Exchange Rates and Fiscal Adjustments - All Countries

Fixers versus Non-Fixers

\begin{tabular}{|c|c|c|c|c|c|c|}
\hline & \multicolumn{3}{|c|}{ Success 3 Years Hence } & \multicolumn{3}{|c|}{ Success 2 Years Hence } \\
\hline & Effective & US Dollar & $\begin{array}{c}\text { Deutsche } \\
\text { Mark }\end{array}$ & Effective & US Dollar & $\begin{array}{c}\text { Deutsche } \\
\text { Mark }\end{array}$ \\
\hline Lagged Debt & $\begin{array}{c}-0,000897 \\
(-0.02)\end{array}$ & $\begin{array}{c}-0,00619 \\
(-0.17)\end{array}$ & $\begin{array}{c}0,00354 \\
(0.10)\end{array}$ & $\begin{array}{c}-0,03052 \\
(-0.82\end{array}$ & $\begin{array}{c}-0,03745 \\
(-1.01)\end{array}$ & $\begin{array}{c}-0,02906 \\
(-0.80)\end{array}$ \\
\hline Lagged GDP growth & $\begin{array}{c}-1,45266 * * \\
(-2.55)\end{array}$ & $\begin{array}{c}-1,07956^{*} \\
(-1.78)\end{array}$ & $\begin{array}{c}-1,61377 * * \\
(-2.83)\end{array}$ & $\begin{array}{c}-1,08832 * \\
(-1.87)\end{array}$ & $\begin{array}{c}-0,69135 \\
(-1.13)\end{array}$ & $\begin{array}{c}-1,2346^{* *} \\
(-2.12)\end{array}$ \\
\hline Change in Deficit & $\begin{array}{c}-4,58967 * * \\
(-5.84)\end{array}$ & $\begin{array}{c}-4,35777 * * \\
(-5.41)\end{array}$ & $\begin{array}{c}-4,67586^{* *} \\
(-5.92)\end{array}$ & $\begin{array}{c}-5,67612 * * \\
(-7.09)\end{array}$ & $\begin{array}{c}-5,41807 * * \\
(-6.68)\end{array}$ & $\begin{array}{c}-5,74643 * * \\
(-7.14)\end{array}$ \\
\hline Change in Gov Consumption & $\begin{array}{l}-9,92 * * \\
(-4.28)\end{array}$ & $\begin{array}{c}-11,20 * * \\
(-4.68)\end{array}$ & $\begin{array}{c}-10,12 * * \\
(-4.37)\end{array}$ & $\begin{array}{c}-11,61 * * \\
(-4.90)\end{array}$ & $\begin{array}{c}-12,93 * * \\
(-5.37)\end{array}$ & $\begin{array}{c}-11,87 * * \\
(-5.03)\end{array}$ \\
\hline $\begin{array}{l}\text { Lagged Change in Exchange Rate } \\
\text { Fixers }\end{array}$ & $\begin{array}{c}-1,07929 * * \\
(-2.19)\end{array}$ & $\begin{array}{c}-0,24384 \\
(-1.26)\end{array}$ & $\begin{array}{c}-0,78694 * * \\
(-2.35)\end{array}$ & $\begin{array}{c}-1,16043^{* *} \\
(-2.28)\end{array}$ & $\begin{array}{c}-0,19202 \\
(-0.99)\end{array}$ & $\begin{array}{c}-0,81983^{* *} \\
(-2.41)\end{array}$ \\
\hline $\begin{array}{l}\text { Lagged Change in M1 } \\
\text { Fixers }\end{array}$ & $\begin{array}{c}-0,11028 \\
(-0.92)\end{array}$ & $\begin{array}{l}-0,079 \\
(-0.64)\end{array}$ & $\begin{array}{c}-0,12437 \\
(-1.01)\end{array}$ & $\begin{array}{c}-0,07619 \\
(-0.62)\end{array}$ & $\begin{array}{c}-0,04183 \\
(-0.34)\end{array}$ & $\begin{array}{c}-0,0887 \\
(-0.71)\end{array}$ \\
\hline $\begin{array}{l}\text { Lagged Change in Exchange Rate } \\
\text { Non-Fixers }\end{array}$ & $\begin{array}{c}-1,05561 * * \\
(-3.52)\end{array}$ & $\begin{array}{c}-0,8895^{* *} \\
(-3.86)\end{array}$ & $\begin{array}{c}-0,65308 * * \\
(-2.52)\end{array}$ & $\begin{array}{c}-0,99605^{* *} \\
(-3.22)\end{array}$ & $\begin{array}{c}-0,92977 * * \\
(-3.99)\end{array}$ & $\begin{array}{l}-0,67878 * * \\
(-2.57)\end{array}$ \\
\hline $\begin{array}{l}\text { Lagged Change in M1 } \\
\text { Non-Fixers }\end{array}$ & $\begin{array}{c}-0,09944 \\
(-0.56) \\
\end{array}$ & $\begin{array}{c}0,02214 \\
(0.13) \\
\end{array}$ & $\begin{array}{c}-0,01259 \\
(-0.07) \\
\end{array}$ & $\begin{array}{c}-0,10744 \\
(-0.59) \\
\end{array}$ & $\begin{array}{c}0,02067 \\
(0.12) \\
\end{array}$ & $\begin{array}{c}-0,02846 \\
(-0.15) \\
\end{array}$ \\
\hline R2 Within & 0,21 & 0,21 & 0,20 & 0,25 & 0,26 & 0,24 \\
\hline R2 Between & 0,40 & 0,34 & 0,38 & 0,33 & 0,26 & 0,34 \\
\hline Nr. Observations & 420,00 & 392,00 & 420,00 & 420,00 & 392,00 & 420,00 \\
\hline
\end{tabular}


Our results on the exchange rate test, for the first time, the contention often made in the literature that successful fiscal adjustments tend to be preceded by exchange rate depreciations. This contention has been presented by several authors but so far based not directly tested against other determinants of persistent adjustments. Giavazzi and Pagano (1990) mention that "several major multi year fiscal adjustments are preceded by a devaluation of the exchange rate." Alesina and Perotti (1997) find that, though there are significant exchange rate depreciations before all type of adjustments, the average depreciation before and during successful adjustments is twice as high. In line with this, decreases in unit labor cost before successful adjustments are twice as high on average than before unsuccessful adjustments. They suggest: "the unit labor cost channel may even be more empirically relevant than the wealth effects and credibility channels on consumption." Finally, consistent with a contribution of the depreciations to the success of adjustments, there is a significant positive increase in the current account only during successful adjustments, suggesting a surge in exports. ${ }^{27}$

\section{Conclusions and implications for EMU}

The empirical literature on the determinants of successful fiscal adjustments has overlooked the role of monetary and exchange rate policies for the success and sustainability of deficit cuts. Our paper presents both a case-study analysis and new empirical estimates of the determinants of the success of fiscal adjustments to highlight the importance of monetary and exchange rate policies.

Successful fiscal adjustments in the OECD during last three decades have typically been preceded by large nominal exchange rate depreciations. Exchange rate depreciations are quantitatively important in predicting success for fiscal adjustments: a 1 percent average depreciation in the two years preceding a fiscal adjustment leads to a roughly 1 percent increase in the probability of success. This effect is quantitatively similar to that of the composition of fiscal adjustment, which measures how much the adjustment relies on cutting spending versus raising tax revenues. Finally, monetary policy does not play a significant role in successful adjustments: around successful adjustments monetary policy simply does not change much.

Economic and Monetary Union in Europe (EMU) has substantially altered the conduct of exchange rate and monetary policies by creating a common currency and the European Central Bank. Among the most conspicuous changes in the policy-making framework in Europe are the fiscal mandates stipulated by the Pact for Stability and

\footnotetext{
${ }^{27}$ See Table 10 in Alesina and Perotti (1997). The authors mention: "both successful and unsuccessful adjustments have been accompanied and preceded by nominal depreciations, somewhat larger in successful cases. However, significant depreciations accompanied unsuccessful adjustments as well. What is interesting is that while in successful cases the nominal depreciations had an impact on competitiveness (unit labor costs) in unsuccessful cases it did not. These observations suggest that the behavior of real wages is significantly different in the two types of adjustments. As argued above, this difference may be linked to the composition of the fiscal adjustment, and in particular to the difference in the behavior of government wages and employment and taxes on households and social security contributions. The evidence on the trade balance confirms the superior performance of net exports in successful versus unsuccessful adjustments."
} 
Growth that accompany the monetary agreement. ${ }^{28}$ The institutional setting is now characterized by centralization of monetary policy while, in the fiscal sphere, national autonomy is kept within the constraints dictated by the Pact. More formally, fiscal budget deficits are mandated to be below 3 percent of GDP, to be exceeded only in case of deep recessions, i.e. real GDP growth rates below -2 percent or, with the concurrence of the Council of Ministers, below -0.75 percent. Countries with excessive deficits that cannot be justified are subject to mandatory deposits and fines if this fiscal excess is not corrected in two years.

The combination of centralized monetary and decentralized, though constrained, fiscal policy raises two different questions. The first question is whether countries are more or less likely to incur deficits in a monetary union. On one hand, the loss of monetary autonomy may increase the use of fiscal policy to respond to asymmetric shocks. On the other hand, both factor and product market integration and the statutory limits discussed above effectively limit fiscal autonomy. ${ }^{29}$ Governments are likely to be constrained by the diminished capacity to raise taxes due to increasing factor (mainly capital) mobility. In the past, governments in Europe have been able to place a substantial part of their debt with their private banks; this situation may change in the future. Moreover, lower seigniorage revenues harden the fiscal budget constraint on the fiscal authority, even though such revenues are typically small in OECD economies.

The second question, the one for which our results are relevant, is whether EMU countries with excessive deficits are in a better position to correct fiscal deficits after EMU. Our paper suggests they are not. Our results show that currency depreciation furthers the likelihood of successful, i.e. persistent, fiscal adjustments. Given that EMU introduced a single currency for all its members and that EMU members trade mostly with each other, it will now be harder for individual countries to correct fiscal imbalances.

Previous evidence by other authors reinforces our case that fiscal adjustments will be harder to undertake after EMU. Eichegreen and Wyplosz (1998) look at the major recession in OECD countries and find seven instances of countries with deficits in excess of 3 percent of GDP in the period 1955-96. By examining the growth rate of GDP and the behavior of the budget deficit, they indicate that these are "snap" recessions in that real GDP growth is negative only for the year of recession and positive in all years immediately before and after. In contrast, the budget deficit increases dramatically in the recession year and stays at values higher than 3 percent of GDP for at least 3 years thereafter. This suggests that, even though instances of exceeding the EMU deficit limits will be rare, once they occur, they are likely to require discretionary fiscal policy measures. In this context, the abandonment of the exchange rate as a policy instrument is an important loss, given its significant impact on the persistence of the adjustment. Obstfeld (1999) points to another reason why EMU countries will find it more difficult to

\footnotetext{
${ }^{28}$ For an overview of the history and the political and economic rationale of monetary unification in Europe see Eichengreen (1993).

${ }^{29}$ Obstfeld (1999) underlines how fiscal and monetary policy will likely be more intertwined in a monetary union. "It is hard to believe that the Euro-11 club of EMU finance ministers will refrain from forceful comment on ECB policy, including but not limited to exchange-rate developments. In its turn, the ECB will surely weigh in on fiscal matters."
} 
undertake successful adjustments: most recent adjustments within EMU are not relying on spending cuts but rather on tax increases (sometimes temporary) which may not be sustainable. In fact, even the European Monetary Institute had expressed reservations about the persistence of the fiscal adjustments undertaken in the build-up to monetary union. Some EMU members have high public debt to GDP ratios that require large interest rate payments and make the fiscal constraints dictated by the Pact for Stability and Growth binding. Our results suggest that a successful adjustment within EMU will become more "costly" as countries that abandon autonomous exchange rate policies must rely entirely on the size and composition of its fiscal cuts to achieve sustainable deficit reductions. 


\section{References}

- Alesina,-Alberto; Ardagna,-Silvia (1998), "Fiscal Adjustments: Why They Can Be Expansionary", Economic-Policy:-A-European-Forum; 0(27), pages 487-517.

- Alesina and Perotti (1995), "Fiscal Expansions and Adjustments in OECD Countries," Economic Policy, 21, pp. 205-48.

- Alesina and Perotti (1997), "Fiscal Adjustments in OECD Countries: Composition and Macroeconomic Effects," International Monetary Fund Staff Papers; 44 (2), June 1997, pp. 210-48.

- Alesina, Perotti and Tavares (1998), "The Political Economy of Fiscal Adjustments," Brookings Papers on Economic Activity, Spring, pp. 197-266.

- Alogoskoufis (1992), "Fiscal Policies, Devaluations and Exchange Rate Regimes: The Stabilization Programmes of Ireland and Greece," Economic and Social Review, pp. 225-46.

- Barro, Robert, (1974), “Are Government Bonds Net Wealth?" The Journal of Political Economy, Vol. 82, No. 6, pp. 1095-1117.

- Bertola,-Giuseppe; Drazen,-Allan, (1993), "Trigger Points and Budget Cuts: Explaining the Effects of Fiscal Austerity", American-Economic-Review; 83(1), pages 11-26.

- Blanchard (1990), "Can Severe Fiscal Contractions Be Expansionary? Tales of Two Small European Countries: Comment", in Blanchard, Olivier-Jean; Fischer,-Stanley, eds. NBER Macroeconomics Annual, 1990. Cambridge, Mass. and London: MIT Press, pp. 111-16.

- Drazen,-Allan (1990), "Can Severe Fiscal Contractions Be Expansionary? Tales of Two Small European Countries: Comment", in Blanchard, Olivier-Jean; Fischer,Stanley, eds. NBER Macroeconomics Annual, 1990. Cambridge, Mass. and London: MIT Press, pp. 117-22.

- Eichengreen (1993), "European Monetary Unification," Journal of Economic Literature, XXXI, September, pp. 1321-1357.

- Eichengreen,-Barry; Wyplosz,-Charles (1998), “The Stability Pact: More Than a Minor Nuisance?" Economic-Policy: A European-Forum; 0 (26), April, pp. 65-104.

- Feldstein, M. (1982), “Government Deficits and Aggregate Demand," Journal of Monetary Economics, 9, pp. 1-20.

- Giavazzi, Japelli and Pagano (2000), "Searching for Non-linear Effects of Fiscal Policy: Evidence From Industrial and Developing Countries," NBER Working Paper 7460, January.

- Giavazzi and Pagano (1990), "Can Severe Fiscal Contractions Be Expansionary? Tales of Two Small European Countries," in Blanchard,-Olivier-Jean; Fischer,Stanley, eds. NBER Macroeconomics Annual 1990. Cambridge, Mass. and London: MIT Press, pp. 75-111.

- Giavazzi and Pagano (1996), "Non-Keynesian Effects of Fiscal Policy Changes: International Evidence and Swedish Experience," Swedish Economic Policy Review, May, pp. 75-111.

- Hjelm, Goran (2000), "Effects of Fiscal Contractions: The importance of Preceding Exchange Rate Movements," manuscript.

- Lane and Perotti (1998),"The Trade Balance and Fiscal Policy in the OECD," European Economic Review, 42, 1998, pp. 887-895. 
- Obstfeld (1999), “EMU: Ready or Not?” NBER Working Paper No. 6682.

- OECD, (1984-85), "Ireland", Economic Surveys, OECD Paris

- OECD, (1982-83), "Denmark”, Economic Surveys, OECD Paris.

- IMF, "International Financial Statistics", International Monetary Fund, Washington, D.C.

- Perotti, R. (1999), "Fiscal Policy in Good Times and Bad," November, Quarterly Journal of Economics.

- Schuknecht (1998), "Fiscal Policy Cycles and the Exchange Regime in Developing Countries," World trade Organization, Staff Working Paper ERAD 97-04, Genéve.

- Sutherland (1997), "Fiscal Crises and Aggregate Demand: Can High Public Debt Reverse the Effects of Fiscal Policy?" Journal of Public Economics, 65, 147-162. 


\section{Appendix I - Data Sources}

GDP- Source: OECD Economic Outlook. Definition: Growth rate of real GDP, computed as the difference between the value in the current year minus the value one year before, divided by the value the year before.Unit: Percentage points.

Nominal Effective Exchange Rate- Source: OECD Economic Outlook. Definition: Growth rate of the nominal effective exchange rate, defined as the difference between the value in the current year minus the value one year before, divided by the value the year before. A positive value denotes an appreciation of the country's currency. Unit: Percentage points.

Nominal Deutsche Mark Exchange Rate- Source: OECD Economic Outlook. Definition: Growth rate of the nominal exchange rate against the Deutsche Mark, defined as the difference between the value in the current year minus the value one year before, divided by the value the year before. The exchange rate versus the Deutsche Mark was computed using the each currency's exchange rate against the United States Dollar and the US Dollar/Deutsche Mark exchange rate. A positive value denotes an appreciation of the country's currency. Unit: Percentage points.

Nominal US Dollar Exchange Rate- Source: OECD Economic Outlook Definition: Growth rate of the nominal exchange rate against the United States Dollar, defined as the difference between the value in the current year minus the value one year before, divided by the value the year before. A positive value denotes an appreciation of the country's currency. Unit: Percentage points.

Real Effective Exchange Rate - Source: OECD Economic Outlook. Definition: Growth rate of the real effective exchange rate, defined as the difference between the value in the current year minus the value one year before, divided by the value the year before. A positive value denotes an appreciation of the country's currency. Unit: Percentage points.

Real Deutsche Mark Exchange Rate - Source: OECD Economic Outlook. Definition: Growth rate of the real exchange rate versus the Deutsche Mark, defined as the growth of the nominal exchange rate against the Deutsche Mark plus the growth in the Consumer Price Index (CPI) at home minus the growth of the Consumer Price Index in Germany. A positive value denotes an appreciation of the country's currency. Unit: Percentage points.

Real US Dollar Exchange Rate - Source: OECD Economic Outlook. Definition: Growth rate of the real exchange rate versus the US Dollar, defined as the growth of the nominal exchange rate against the US Dollar plus the growth in the Consumer Price Index (CPI) at home minus the growth of the Consumer Price Index in the United States. A positive value denotes an appreciation of the country's currency. Unit: Percentage points.

Exchange Rate Regime - Source: International Monetary Fund. Definition: A Non-fixer country is any country classified by the International Monetary Fund as a "freely floating regime" (between 1970 and 1974), the exchange rate is not maintained in "relatively narrow 
bands" (between 1974 and 1978) or it is "independently floating" (after 1978). All other country-years are considered fixers, i.e., under a fixed exchange rate regime.

M1 - Source: IMF International Financial Statistics. Definition: Growth rate of M1 monetary aggregate computed as the difference between the value in the current year minus the value one year before, divided by the value the year before. Unit: Percentage points.

Inflation - Source: IMF International Financial Statistics. Definition: Growth rate of the Consumer Price Index computed as the difference between the value in the current year minus the value one year before, divided by the value the year before. Unit: Percentage points.

Lagged Debt Level - Source: OECD Economic Outlook. Definition: Government Net Financial Liabilities as a Share of Gross Domestic Product one year before the fiscal adjustment. Unit: Percentage points.

Change in Deficit - Source: OECD Economic Outlook. Definition: Total change in the public deficit as a share of Gross Domestic product in year of the fiscal adjustment, corrected for the cycle. A positive value indicates an increase in the public deficit. Unit: Percentage points.

Change in Government Consumption - Source: OECD Economic Outlook. Definition: Change in the level of government consumption as a share of GDP in the year of the fiscal adjustment. Unit: Percentage points. 
Figure 1

Deutsche Mark/Irish Punt exchange rate (daily)

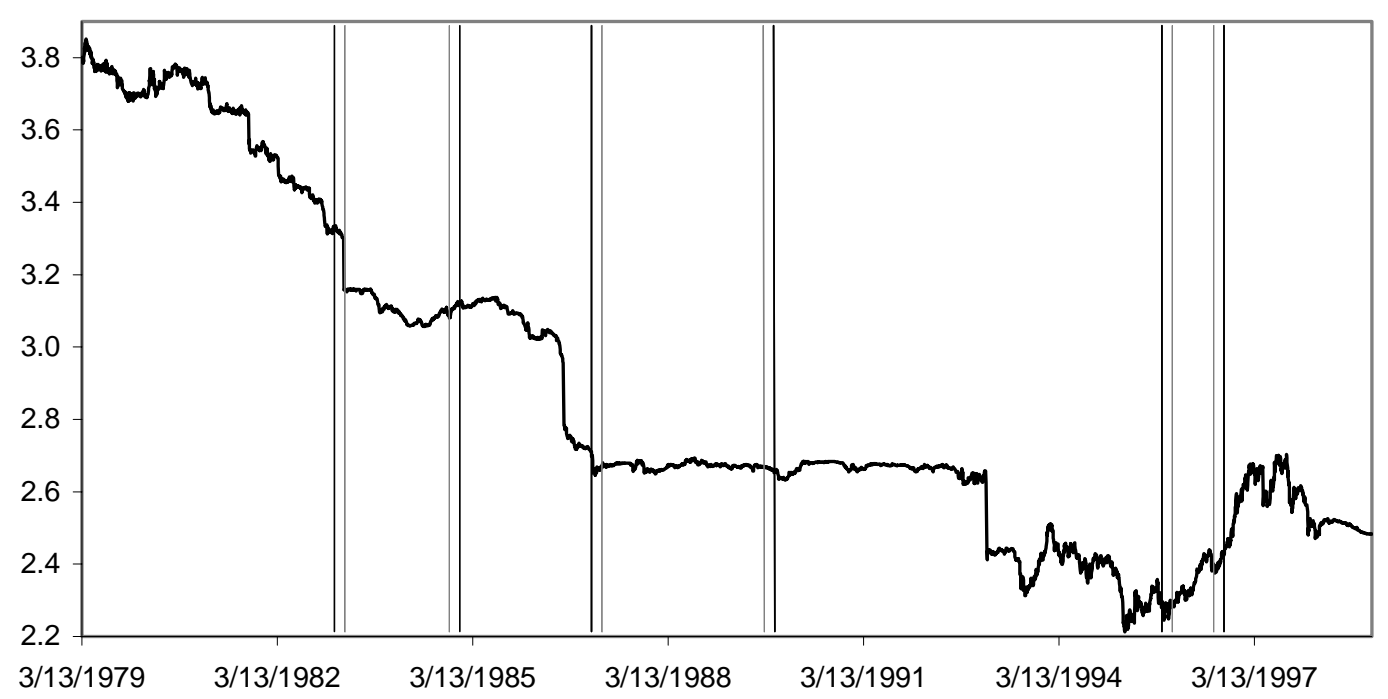

Figure 2

Irish real effective exchange rate (monthly)

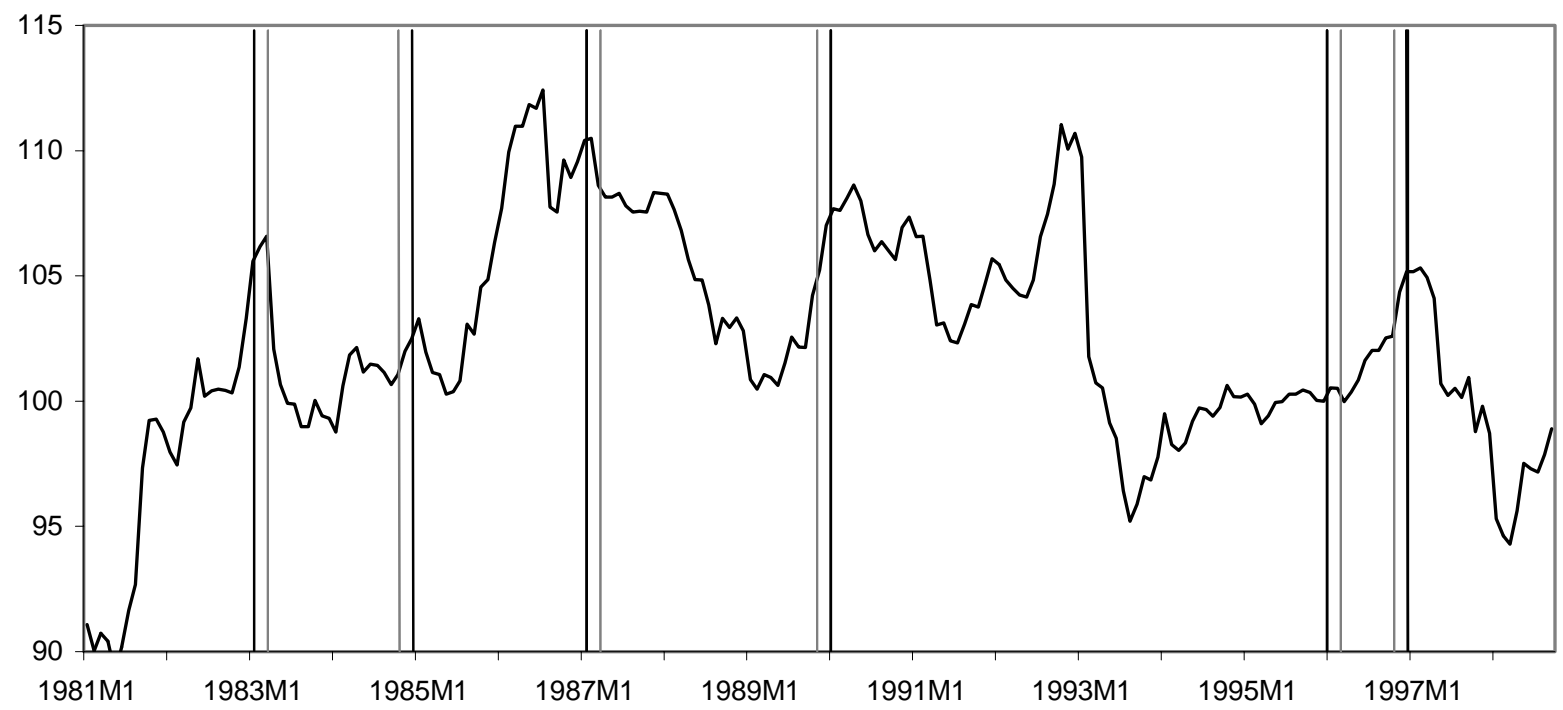


Figure 3

Deutsche Mark/Danish Krona exchange rate (daily)

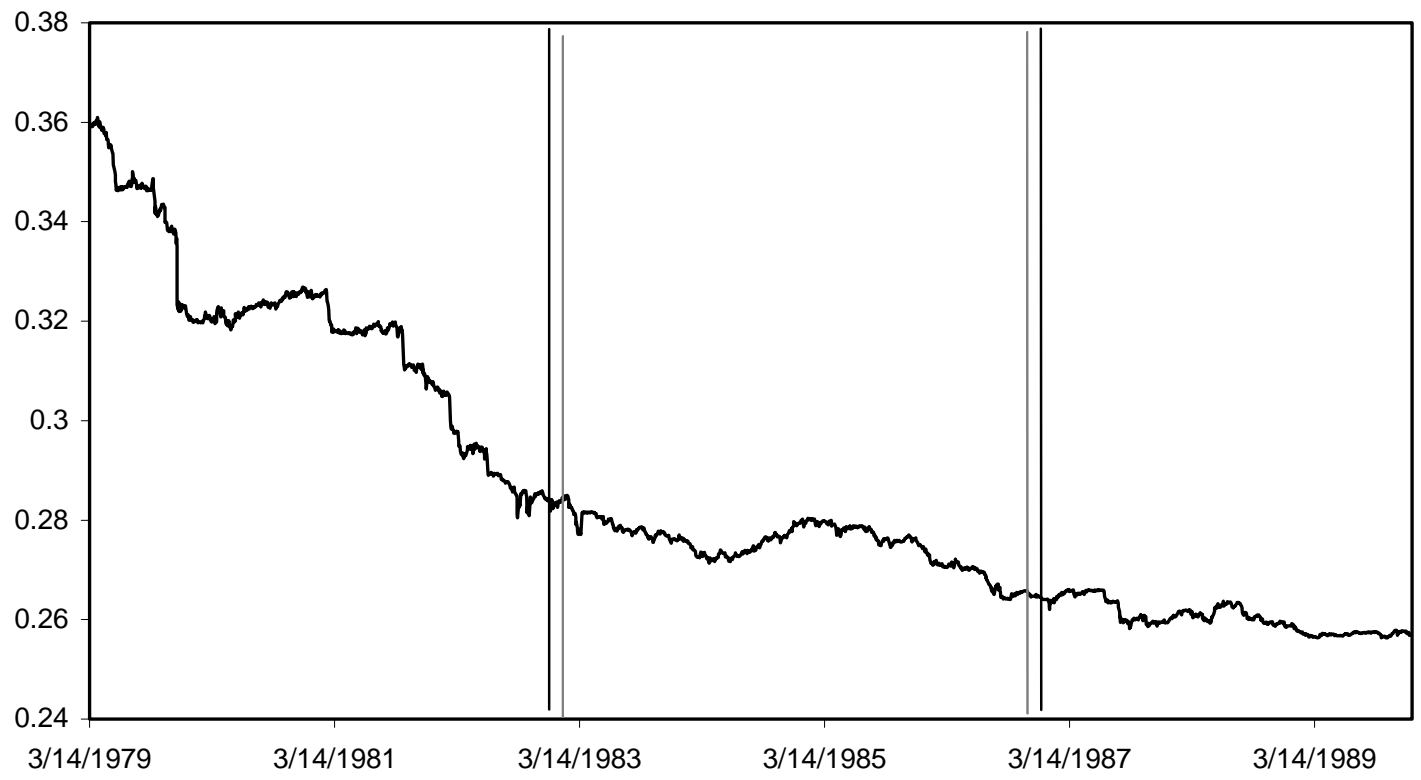

Figure 4

Danish real effective exchange rate (monthly)

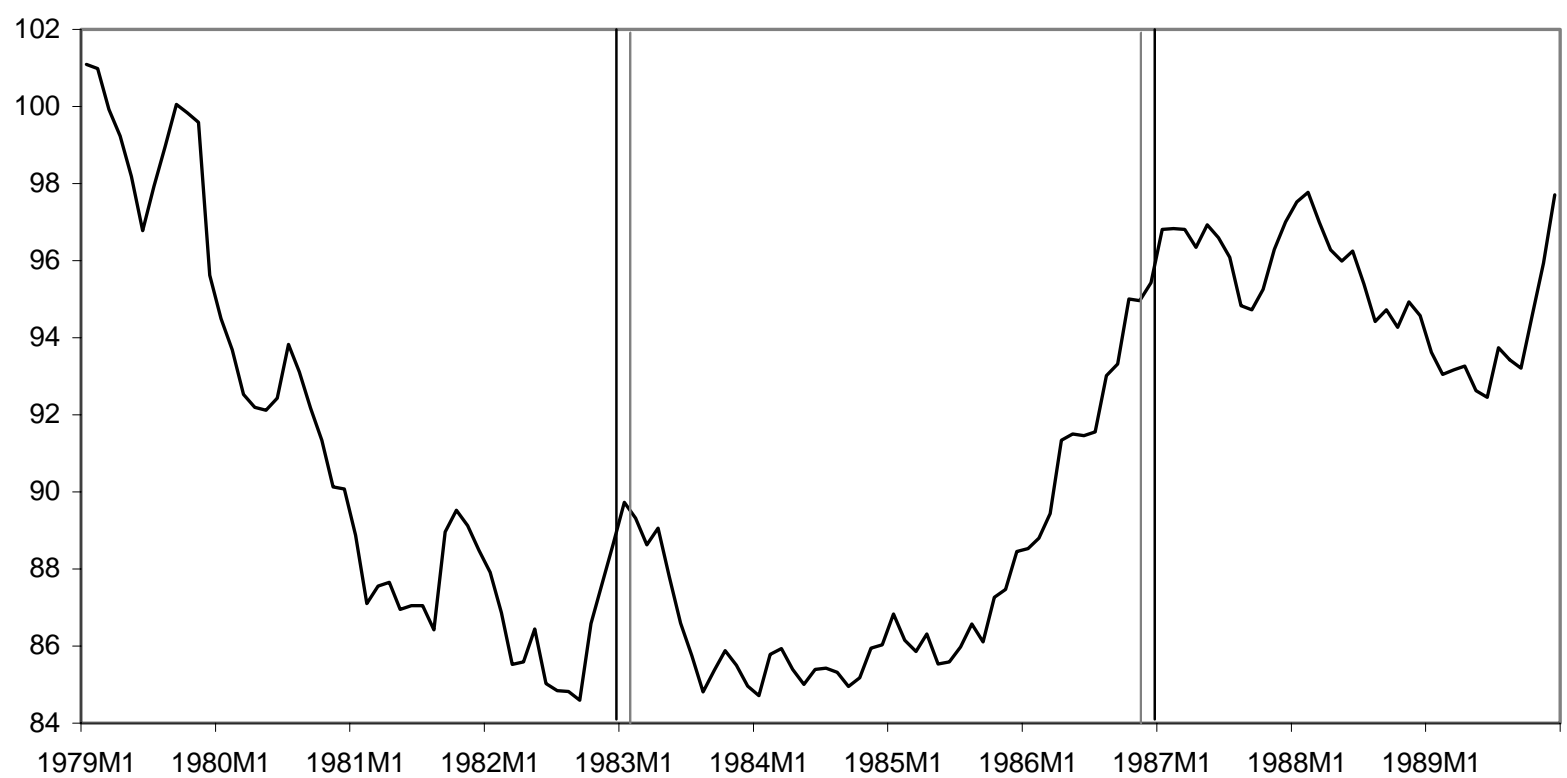


Figure 5

Deutsche Mark/Swedish Krona exchange rate (daily)

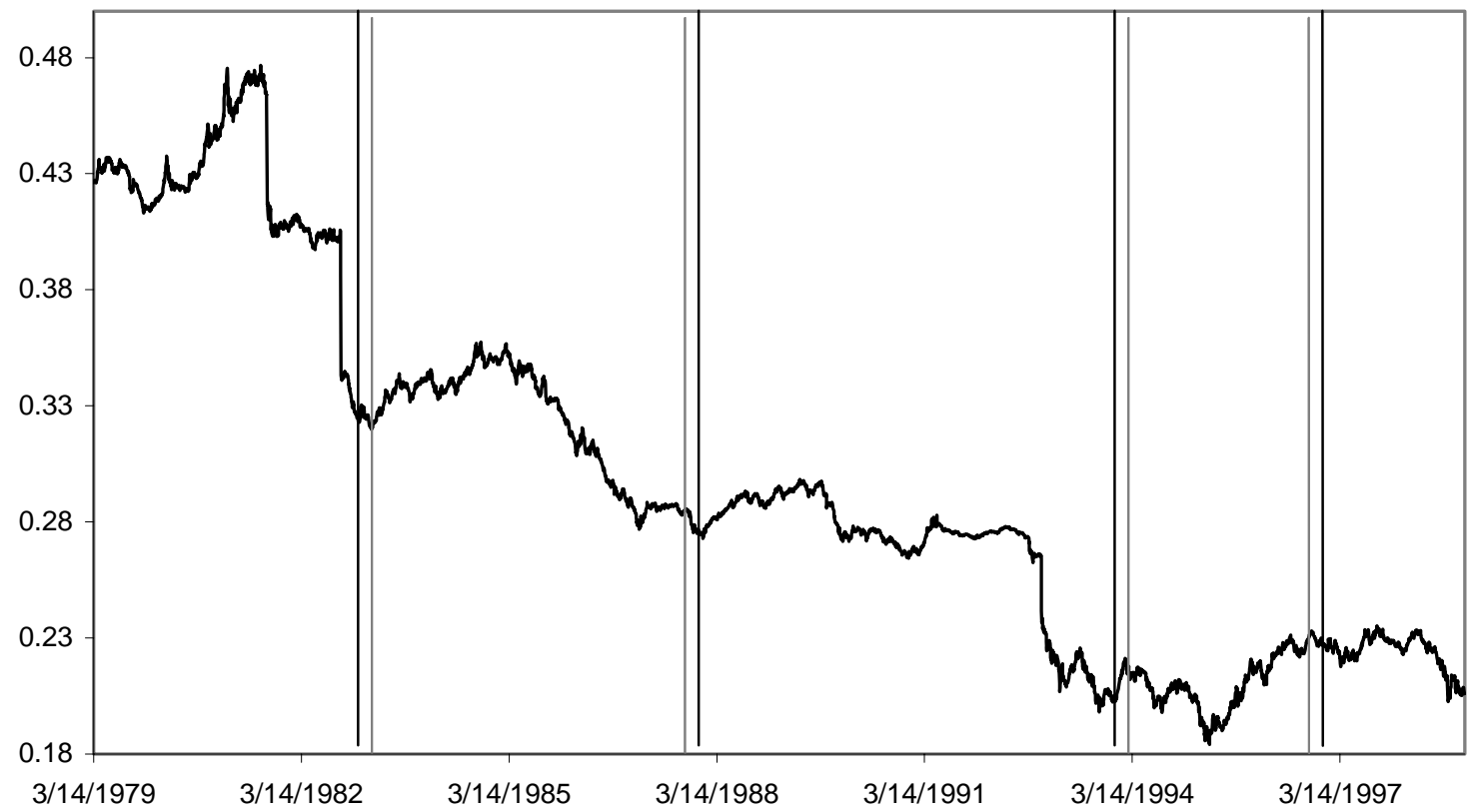

Figure 6:

Swedish real effective exchange rate (monthly)

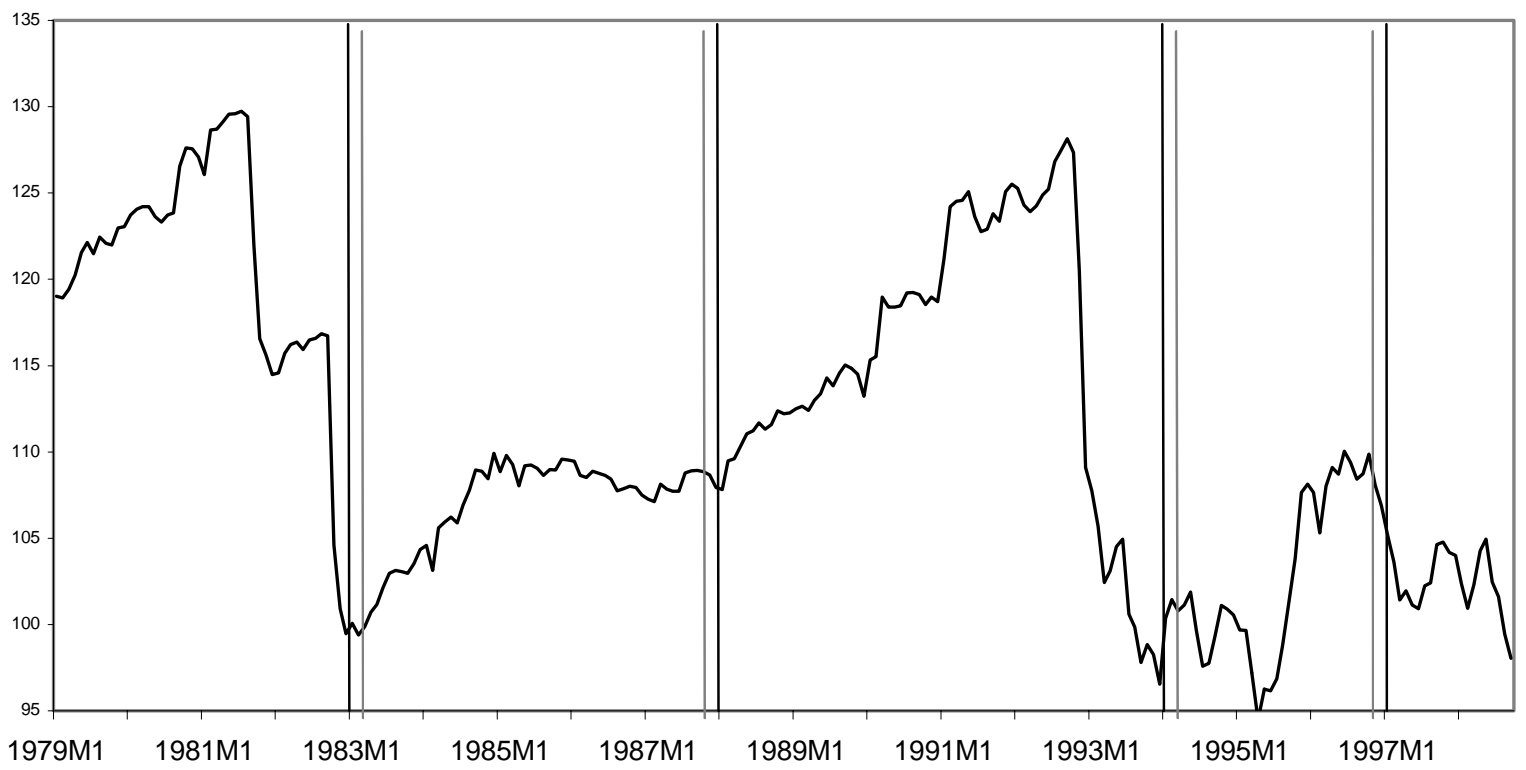

